\title{
PW02-012 - First clinical description of an infant with DITRA
}

\author{
L Rossi-Semerano ${ }^{1 *}$, M Piram ${ }^{1}$, C Chiaverini ${ }^{2}$, D De Ricaud ${ }^{3}$, A Smahi ${ }^{4}$, I Koné-Paut ${ }^{5}$ \\ From 7th Congress of International Society of Systemic Auto-Inflammatory Diseases (ISSAID) \\ Lausanne, Switerland. 22-26 May 2013
}

\begin{abstract}
Introduction
Interleukin-36-receptor antagonist deficiency (DITRA) is a recently described auto-inflammatory disease ${ }^{1}$, characterized by repeated flares of generalized pustular psoriasis, high fever, asthenia and systemic inflammation. This condition is caused by homozygous missense mutation in the IL36RN gene, encoding the interleukin-36-receptor antagonist (IL-36Ra), an anti-inflammatory cytokine. We report herein the first exhaustive clinical description of an infant with DITRA, who was successfully treated with anakinra.
\end{abstract}

\section{Case report}

Y.M. is the first son of Tunisian consanguineous parents who developed, at two weeks of life, an erythematous and scaly eruption, with subsequent rapid evolution toward generalized pustular psoriasis. Afterwards, cutaneous flares of diffuse erythematous rash and pustules involving the whole body appeared, with a once weekly periodicity. Intense irritability was present during flares without fever. Moreover, since 1 month of age the infant presented diarrhea, dysphagia and reduced feeding rate, with failure to thrive. Laboratory tests during acute flares showed marked leukocytosis, thrombocytosis and anemia without C-reactive protein elevation. Skin biopsy and clinical presentation were consistent with pustular psoriasis, nevertheless, the patient did not respond to high-potency topical corticosteroids and retinoid acid.

As the patient presented repeated skin flares early after birth, as well as serious constitutional distress with failure to thrive, an auto-inflammatory syndrome like DIRA (interleukine-1 receptor antagonist deficiency)[2] or DITRA was considered. The hypothesis was reinforced

\footnotetext{
'Department of Paediatrics and Paediatric Rheumatology, Bicêtre Hospital, National Reference Centre for Auto-inflammatory Diseases, Le KremlinBicêtre, France

Full list of author information is available at the end of the article
}

by parental consanguinity, and absence of skin lesions improvement under standard topical treatment. Genetic analyses showed a homozygous mutation in the IL36RN gene (L27P) which represents the same mutation recently described in DITRA patients[1,3]. At 6 months we started treatment with the recombinant IL-1 receptor antagonist anakinra with efficacy both on constitutional symptoms and skin involvement.

\section{Discussion}

To the best of our knowledge, we report the first detailed clinical description of an infant with DITRA. Even if neonatal onset has been already reported[1], no detailed clinical description was provided, probably due to late diagnosis. Our clinical report brings new clinical characteristics and educational iconography.We even report, for the first time, a favorable clinical response of this disease to anakinra treatment.

\section{Disclosure of interest}

L. Rossi-Semerano: None Declared, M. Piram: None Declared, C. Chiaverini: None Declared, D. De Ricaud: None Declared, A. Smahi: None Declared, I. Koné-Paut Grant / Research Support from: Educational and research grant from Swedish Orphan Biovitrum, Consultant for: Consultant fee from Novartis

\begin{abstract}
Authors' details
'Department of Paediatrics and Paediatric Rheumatology, Bicêtre Hospital, National Reference Centre for Auto-inflammatory Diseases, Le KremlinBicêtre, France. ${ }^{2}$ Service de dermatologie et centre de référence des épidermolyses bulleuses héréditaires Hôpital Archet $2 \mathrm{CHU}$ de Nice, France. ${ }^{3}$ Service de pédiatrie, GCS CHU-Lenval, Nice, France. ${ }^{4}$ U781 INSERM, Hôpital Necker Enfants Malades, Paris, France. ${ }^{5}$ Department of Paediatrics and Paediatric Rheumatology, Bicêtre Hospital, National Reference Centre for Auto-inflammatory Diseases, Le Kremlin Bicêtre, France.
\end{abstract}

Published: 8 November 2013 


\section{References}

1. Marrakchi S, Guigue P, Renshaw BR, et al: Interleukin-36-receptor antagonist deficiency and generalized pustular psoriasis. N Engl I Med 2011, 365(7):620-8.

2. Aksentijevich I, Masters SL, Ferguson PJ, et al: An Autoinflammatory Disease with Deficiency of the Interleukin-1-Receptor Antagonist. N Engl J Med 2009, 360(23):2426-2437, doi:10.1056/NEJMoa0807865.

3. Onoufriadis A, Simpson MA, Pink AE, et al: Mutations in IL36RN/IL1F5 are associated with the severe episodic inflammatory skin disease known as generalized pustular psoriasis. Am J Hum Genet 2011, 89(3):432-437.

doi:10.1186/1546-0096-11-S1-A152

Cite this article as: Rossi-Semerano et al: PW02-012 - First clinical description of an infant with DITRA. Pediatric Rheumatology 201311 (Suppl 1):A152.

Submit your next manuscript to BioMed Central and take full advantage of:

- Convenient online submission

- Thorough peer review

- No space constraints or color figure charges

- Immediate publication on acceptance

- Inclusion in PubMed, CAS, Scopus and Google Scholar

- Research which is freely available for redistribution

Submit your manuscript at www.biomedcentral.com/submit 